\title{
Status Kepemilikan Tanah Adat Di Bali Yang Diakui Sebagai Tanah Milik Pribadi
}

\section{Putu Indi Apriyani ${ }^{1}$}

1Magister Kenotariatan Fakultas Hukum Universitas Udayana, E-mail: indiapriyanip@gmail.com/WA : 081238553367

\section{Info Artikel \\ Keywords : \\ Status of Ownership, \\ Customary Land, Article 9 paragraph (5) Bali Provincial Regulation 3/2003 Pakraman Village.}

Kata kunci:

Status Kepemilikan, Tanah Adat, Pasal 9 ayat (5) Perda Provinsi Bali 3/2003 Desa Pakraman.

\begin{abstract}
Based on the provisions of Article 9 paragraph (5) Regional Regulation of Bali Province Number 3 of 2001 concerning Pakraman Village juncto Regional Regulation of Bali Province Number 3 of 2003 concerning changes in Bali Provincial Regulation Number 3 of 2001 concerning Pakraman Village, it has been clearly determined that village land and or land owned by Pakraman village cannot be certified in private name. Sociologically, there is still a gap between the regulation of village land (das sollen) and its implementation regarding the ownership status of village land (das sein). From the description of the previous background, there are formulations of the problem, among others: (1) What are the factors that cause the number of customary lands in Bali to be recognized as private property? and (2) How are efforts to reduce customary land in Bali to private property? The purpose of this study was to analyze the factors that caused customary land in Bali to be private land. The method used in this paper is an empirical legal research method by examining primary data and secondary data with library observation and literature techniques. The results of this study indicate that: (1) the lack of legal awareness of indigenous peoples to comply with legal norms, then the lack of community support in the implementation of legal norms and intentions in ignoring legal norms. And (2) certifying the customary land by making Pakraman village as its legal subject, considering the Appointment of Pakraman Village in Bali Province as the Subject of Land-based Joint Communal Law based on Minister of Agrarian and Spatial Planning National Land Agency Number 276 / KEP-19.2 / X/2017.
\end{abstract}

\section{Abstrak}

Berdasarkan ketentuan Pasal 9 ayat (5) Peraturan Daerah Provinsi Bali Nomor 3 Tahun 2001 Tentang Desa Pakraman juncto Peraturan Daerah Provinsi Bali Nomor 3 Tahun 2003 Tentang perubahan Peraturan Daerah Provinsi Bali Nomor 3 Tahun 2001 Tentang Desa Pakraman, telah ditentukan secara jelas bahwa tanah desa dan atau tanah milik desa pakraman tidak dapat disertifikatkan atas nama pribadi. 
Corresponding Author: Putu Indi Apriyani, E-mail: indiapriyanip@gmail.com

DOI :

10.24843/AC.2018.v03.i02.p10
Secara sosiologis masih ditemukan kesenjangan antara pengaturan tentang tanah desa (das sollen) dan pelaksanaannya terkait status kepemilikan tanah desa (das sein). Dari uraian latar blakang sebelumnya, terdapat rumusan masalah antara lain : (1) Apa faktor yang menyebabkan banyaknya tanah adat di Bali diakui sebagai tanah milik pribadi ? dan (2) Bagaimana upaya untuk mengurangi tanah adat di Bali menjadi tanah milik pribadi ?. Tujuan studi ini untuk menganalisis faktor yang menyebabkan tanah adat di Bali menjadi tanah pribadi. Metode yang dipergunakan dalam penulisan ini adalah metode penelitian hukum empiris dengan meneliti data primer serta data sekunder dengan teknik observasi dan studi kepustakaan. Hasil penelitian ini menunjukan bahwa: (1) kurangnya kesadaran hukum masyarakat hukum adat untuk mentaati norma hukum, kemudian kurangnya dukungan masyarakat dalam pelaksanaan norma hukum dan kesengajaan dalam mengabaikan norma hukum. Dan (2) mensertifikatkan tanah adat tersebut dengan menjadikan desa pakraman sebagai subyek hukumnya, mengingat tentang Penunjukan Desa Pakraman Di Provinsi Bali Sebagai Subyek Hukum Pemilikan Bersama (Komunal) Atas Tanah berdasarkan Keputusan Menteri Agraria Dan Tata Ruang Badan Pertanahan Nasional Nomor 276/KEP-19.2/X/2017.

\section{Pendahuluan}

Manusia berpijak dan melangsungkan kehidupannya di atas tanah, sehingga tanpa tanah, manusia tidak bisa hidup. Hubungan tanah dan manusia sangat erat, ibaratkan seperti hubungan ibu dengan anak, maka dari itu semua hal yang berhubungan dengan tanah selalu menjadi pusat perhatian maka dari itu tidak heran apabila semua individu ingin memiliki tanah.

Begitu banyaknya peran tanah, maka dari itu Pemerintah Negara Republik Indonesia membuat peraturan yang mengatur mengenai tanah, yang ditentukan pada Hukum Nasional serta Hukum Adat, namun sebelumnya telah berlaku hukum (peraturan) tanah yang memiliki sifat dualistis, yakni diundangkannya hukum (peraturan) tanah barat bersamaan dengan hukum adat tanah. Hukum (peraturan) tanah barat tersebut, diperuntukan pada tanah-tanah atas hak-hak barat, seperti salah satunya hak eingendom, tanah erpacht, tanah opstal serta yang lain-lainnya, kemudian hukum (peraturan) adat tanah ini diperuntukan terhadap tanah-tanah yang dikenal dengan hak-hak- Indonesia, yang serupa halnya dengan tanah usaha, tanah milik, tanah gogolan tanah bengkok serta yang lainnya. ${ }^{1}$ Sesudah diundangkannya UndangUndang Pokok Agraria (UUPA), dualisme itu dihilangkan, kemudian diberlakukannya hukum tanah (hukum agraria) nasional yang berdasarkan kepada norma adat. Hukum Adat dipergunakan sebagai pedoman dalam hukum nasional yang ditentukan pada

\footnotetext{
1 Yanto Sufriadi. (2011). Penyebab Sengketa Pengadaan Tanah Untuk Kepentingan Umum (Studi Kasus Sengketa Pengadaan Tanah Untuk Kepentingan Umum Di Bengkulu). Jurnal Hukum, 1(18). 42-62, h. 47.
} 
ketentuan Pasal 5 UUPA yanh menentukan bahwa hukum agraria yang berlaku adalah hukum adat, selama tidak berbenturan terhadap kepentingan nasional serta Negara. ${ }^{2}$ Pada ketentuan tersebut telah memberi penekanan bahwa hukum adat dipergunakan sebagai landasan dari hukum agraria, namun hukum adat yang diberlakukan adalah hukum adat yang sudah disesuaikan pada persyaratan-persyaratan yang sudah ditentukan, sehingga bukan hukum adat yang asli.

Bagi masyarakat hukum adat di Bali, selain yang sudah ditentukan oleh hukum (peraturan) tanah nasional, masih terdapat komponen-komponen tertentu dari tanah yang diatur menurut hukum (peraturan) adat, contohnya seperti tanah-tanah adat. Tanah adat dalam artian sebagai simbol "milik" masyarakat (warga) hukum adat, memiliki kedudukan dan manfaat yang penting pada kehidupan masyarakat (warga) hukum adat (desa pakraman) di Bali. Berdasarkan ketentuan Pasal 9 (5) Peraturan Daerah Provinsi Bali Nomor 3 Tahun 2001 mengenai Desa Pakraman juncto Peraturan Daerah Provinsi Bali Nomor 3 Tahun 2003 Tentang perubahan Peraturan Daerah Provinsi Bali Nomor 3 Tahun 2001 mengenai Desa Pakraman, telah ditentukan secara jelas bahwa tanah desa atau yang disebut dengan tanah milik desa pakraman tidak boleh disertifikatkan atas hak milik pribadi. Melihat peraturan tersebut, sudah secara jelas dan tegas diatur terkait tanah desa, namun secara sosiologis masih ditemukannya permasalahan terkait tanah adat yang diakui sebagai milik pribadi, hal ini menimbulkan kesenjangan antara pengaturan tentang tanah adat (das sollen) terhadap pelaksanaanya terkait diakuinya tanah adat sebagai milik pribadi (das sein). Dalam tulisan ini, fokus kajiannya lebih ditekankan pada faktor yang menyebabkan banyaknya tanah adat di Bali diakui sebagai tanah milik pribadi serta upaya untuk mengurangi tanah adat di Bali menjadi tanah milik pribadi.

\section{Metode Penelitian}

Karya tulis ini menggunakan penelitian hukum empiris. Menurut Bahder Johan Nasution, pengkajian hukum empiris merupakan pengkajian mengenai gejala-gejala sosial dalam masyarakat maupun gejala mengenai berlangsungnya hukum dalam kehidupan masyarakat. ${ }^{3}$ Karya tulis ini didasarkan atas adanya kesenjangan antara pengaturan tanah adat pada ketentuan Pasal 9 ayat (5) Peraturan Daerah Provinsi Bali Nomor 3 Tahun 2003 mengenai Desa Pakraman (das sollen) terhadap pelaksanaannya terkait diakuinya tanah adat sebagai milik pribadi (das sein). Menggunakan pendekatan kasus (case approach) serta pendekatan undang-undang (statue approach). Pendekatan undang-undang dilaksanakan dengan mengamati Peraturan Daerah Provinsi Bali Nomor 3 Tahun 2003 mengenai Desa Pakraman serta aturan-aturan lainnya yang berkaitan dengan status kepemilikan tanah adat di Bali, sedangkan pendekatan kasus dilakukan dengan mengamati permasalahan tanah adat yang terjadi dalam kehidupan masyarakat hukum adat di Bali, dengan menggunakan sumber data yakni data primer serta data sekunder. Sumber data primer berasal dari pengkajian di wilayah Kabupaten Badung. Asal mula data sekunder adalah data yang didapat melalui undang-undang, jurnal nasional, tesis dan disertasi. Data primer dan data

\footnotetext{
2 Afifah Kusumadara. (2013). Perkembangan Hak Negara Atas Tanah : Hak Menguasai Atau Hak Memiliki ?. Jurnal Media Hukum, 20 (2), 263-276. h. 265.

${ }^{3}$ Nasution, Bahder Johan. (2008). Metode Penelitian Ilmu Hukum. Bandung : Mandar Maju, h. 135.
} 
sekunder dikumpulkan melalui metode pengumpulan data primer serta metode pengumpulan data sekunder. Metode pengumpulan data primer dilaksanakan melalui pengamatan yaitu mengadakan pengamatan terhadap gejala-gejala sosial yang terjadi dalam kehidupan masyarakat hukum adat di wilayah Kabupaten Badung. Teknik pengumpulan data sekunder dilaksanakan melalui pengkajian kepustakaan termasuk penelitian terhadap undang-udnang, jurnal hukun, tesis, disertasi dan referensi-referensi pengampu yang lain yang tepat dengan persoalan yang ada pada penelitian ini. Karya tulis ini dianalisis memakai metode analisis kualitatif yaitu semua data yang terhimpun baik data yang terhimpun dari data primer yang didapatkan melalui hasil observasi ataupun data sekunder yang didapat melalui hasil studi kepustakaan, akan dikerjakan serta dikaji, antara data yang satu dihubungkan dengan data lainnya kemudian dilakukan intepretasi dan penafsiran sampai dalam bagian analisis dengan cara kualitatif selanjutnya data akan disimpulkan dengan cara deskriftif kualitatif serta sistematis.

\section{Hasil Dan Pembahasan}

\subsection{Faktor Yang Menyebabkan Banyaknya Tanah Adat Di Bali Diakui Sebagai Tanah Milik Pribadi}

Dalam konteks ini, perlu diketahui bahwa tanah yang berhubungan dengan perkumpulan masyarakat hukum adat disebut menggunakan istilah "tanah ulayat". 4 Tanah ulayat merupakan sebagai tanah hak persekutuan warga hukum adat, sehingga di Bali disebut menggunakan istilah "tanah druwe desa" atau "tanah milik desa". Untuk mengkaji permasalahan ini, akan menggunakan Teori Efektivitas Hukum, sebab akan mengkaji ke efektifan norma hukum dalam kehidupan masyarakat dan untuk menganalisis hal-hal yang menyebabkan keberhasilan, kegagalan keberlangsungan serta implementasi hukum tersebut.

Berkaitan dengan teori tersebut, dalam konteks ini aturan pada undang-undang baik yang kedudukannya lebih tinggi ataupun yang lebih rendah memiliki tujuan supaya warga ataupun para penegak hukum bisa melakukannya dengan stabil serta tidak pilih kasih antara warga yang satu terhadap warga yang lain, dengan kata lain dimana seluruh individu dilihat sama kedudukannya di depan hukum (equality before the law). Pada kenyataannya, peraturan perundang-undangan yang telah ditetapkan sering tidak dipatuhi, oleh karena itu peraturan tersebut menjadi tidak berjalan dengan baik, dengan tidak efektifnya norma-norma hukum itu, dapat terjadi oleh sebab peraturan hukumnya tidak jelas atau kabur, kemudian bisa juga penegak hukumnya yang tidak komitmen maupun warganya yang tidak berkontributif terhadap perturanperaturan itu. Perundang-undanganan dinyatakan efektif, jika itu dilakukan dengan benar. 5 Dinyatakan efektif yang dalam artian bahwa jelasnya undang-undang kemudian tidak perlu diadakannya penafsiran serta konsistennya aparat dalam menegakan hukum diimbangi dengan adanya dukungan dari masyarakat untuk melaksanakan aturan tersebut.

\footnotetext{
${ }^{4}$ Didik Wihardi. (2010). Sistem Konversi Hak Atas Tanah Adat Kampung Naga. Bandung. Jurnal Sosioteknologi Institut Teknologi, 20 (9), h. 883.

${ }^{5}$ HS, H. Salim dan Erlies Septiana Nurbani. (2013). Penerapan Teori Hukum Pada Penelitian Tesis Dan Disertasi. Jakarta : PT RajaGrafindo Persada, h. 301.
} 
Relevansi teori ini dipergunakan untuk mengkaji permasalahan pertama, sebab berkaitan dengan kesenjangan antara pengaturan tentang tanah adat pada ketentuan Pasal 9 (5) Peraturan Daerah Provinsi Bali Nomor 3 Tahun 2003 mengenai Desa Pakraman dengan pelaksanaanya dalam kehidupan masyarakat yang belum berjalan dengan baik. Dalam konteks ini, tanah adat di Bali sampai saat ini masih menjadi suatu hal yang dipermasalahkan dalam kehidupan masyarakat di Bali. Permasalahan tanah adat ini, dikarenakan status tanah adat yang awalnya milik desa pakraman, kini beralih menjadi milik pribadi.

Berdasarkan ketentuan Pasal 9 (5) Peraturan Daerah Provinsi Bali Nomor 3 Tahun 2003 mengenai Desa Pakraman, telah ditetukan yakni tanah desa atau yang disebut dengan tanah milik desa pakraman tidak boleh disertifikatkan atas hak milik pribadi. Pada aturan tersebut telah dengan tegas menentukan bahwa tanah adat tidak dapat diakui sebagai milik pribadi, apalagi disertifikatkan atas nama pribadi. Realitasnya, kini masih banyak kasus-kasus terkait tanah adat yang disertifikatkan dan diakui sebagai milik pribadi, padahal sudah ada norma hukum yang dengan tegas mengatur status tanah adat tersebut, namun masih saja tidak ditaati oleh masyarakat. Hal inilah yang akan dikaji beradasarkan teori efektivitas hukum, yang dalam hal ini terdapat 3 unsur yang mengkaji teori efektivitas hukum,antara lain sebagai berikut :

1. Keberhasilah pada pelaksanaan hukum.

2. Ketidakberhasilan pada pelaksanaan hukum.

3. Unsur-unsur yang mempengaruhinya. ${ }^{6}$

Berhasilnya implementasi hukum yang berarti bahwa hukum yang dirancang tersebut terwujud makna dan tujuannya, sehingga makna dari aturan hukum yaitu menata keinginan manusia, maka dari itu jika norma hukum tersebut dipatuhi serta dijalankan oleh warga ataupun aparat penegak hukum, sehingga pelaksanaan hukum tersebut dinyatakan efektif dengan kata lain tidak gagal di dalam perwujudannya. ${ }^{7}$ Sebaliknya, ketidakberhasilan di dalam implementasi hukum yang berarti bahwa norma-norma hukum yaang sudah diterapkan tak tercapai maksud dan tujuannya atau dengan kata lain tidak berhasil dalam implementasinya. Hal tersebut dipengaruhi oleh beberapa faktor - faktor dalam pelaksanaan dan penerapan hukum tersebut, yang meliputi :

1. Unsur keberhasilannya

2. Unsur kegagalannya

Berhasilnya norma hukum dipengaruhi oleh faktor-faktor yang meliputi substansi hukum, kultur, struktur dan fasilitasnya. Jikalau aturan hukum itu dipatuhi serta dijalankan oleh warga ataupun oleh aparatur penegak hukum, sehingga norma tersebut dinyatakan sukses dalam pelaksanaannya, kemudian apabila aturan hukum tersebut kabur maupun kurang jelas serta para aparat hukumnya korupsi dan atau warganya yang tidak menyadari maupun tidak mematuhi norma hukum maupun sarana yang tersedia guna mendukung perwujudan hukum sangat sedikit, disinilah norma hukum tersebut gagal dalam implementasinya.

\footnotetext{
${ }^{6} \mathrm{Ibid}, \mathrm{h} .303$.

7 Hayatul Ismi. (2013). Pengakuan Dan Perlindungan Hukum Hak Masyarakat Adat Atas Tanah Ulayat Dalam Upaya Pembaharuan Hukum Nasional. Jurnal Universitas Riau, 1 (3). H. 23.
} 
Berkaitan dengan ketentuan Pasal 9 (5) Peraturan Daerah Provinsi Bali Nomor 3 Tahun 2003 mengenai Desa Pakraman, bahwa dikaji dari aspek keberhasilannya, pada peraturan ini belum dapat dikatakan efektif atau berhasil dalam implementasinya, sehingga dapat dikatakan bahwa peraturan tersebut belum efektif atau gagal dalam pelaksanaannya dalam masyarakat. Hal ini dikaji dari aspek kegagalannya, yang mana unsur-unsur dari aspek kegagalan peraturan ini terpenuhi yaitu salah satunya yang paling relevan sesuai dengan hasil observasi di Desa Adat Semate, Kelurahan Abianbase, Kecamatan Mengwi, Kabupaten Badung, yang dilaksanakan pada tanggal 23 Agustus 2018. Berdasarkan hasil wawancara dengan salah satu tokoh adat yaitu Bapak I Gede Suryadi, SH., selaku bendesa adat di Desa Adat Semate, Kelurahan Abianbase, Kecamatan Mengwi, Kabupaten Badung, bahwa terjadinya pensertifikatan maupun pengakuan terhadap tanah adat sebagai tanah milik pribadi, disebabkan oleh kurangnya kesadaran hukum masyarakat terhadap norma hukum dan sedikitnya dukungan masyarakat dalam pelaksanaan hukum tersebut, sehingga sampai saat ini masih adanya kasus-kasus tanah adat yang diakui sebagai milik pribadi oleh masyarakat.

Secara sosiologis, konflik adat ini lazimnya terjadi antara warga desa dengan sesamanya, antara masyarakat desa warga desa maupun persekutuan dengan desa. Adapun yang melatarbelakangi timbulnya permasalahan antara lain dikarenakan oleh terdapatnya perubahan sosial yang muncul dalam tingkah laku masyarakat serta adanya peralihan nilai-nilai suatu. ${ }^{8}$ Pada kehidupan masyarakat yang bercirikan oleh cepatnya perubahan ilmu pengetahuan serta teknologi, sehingga dalam masyarakat (warga) adat muncul kesadaran untuk membenahi diri, untuk dapat melangsungkan perubahan (perkembangan) kehidupan warga (masyarakat) yang makin maju. Keadaan itu mengakibatkan adanya perubahan sosial yang mempengaruhi peralihan nilai budaya warga (masyarakat). Nilai-nilai yang telah mapan pada kehidupan warga (masyarakat) menjadi beralih yang dalam konteks ini, adanya peralihan nilai sakral berubah menjadi profane serta nilai agama beralih menjadi nilai ekonomi. Dengan timbulnya peralihan nilai pada warga (masyarakat), sehingga munculah kepentingan yang bersifat pribadi yang bisa bertolak belakang dengan kepentingan warga, maka dari itulah akan menimbulkan permasalahan adat. ${ }^{9}$

Wujud-wujud permasalahan adat yang muncul pada masyarakat (warga) adat Bali mencakup bermacam unsur seperti pada unsur sosial, agama, ekonomi serta budaya. Permasalahan adat sebagai permasalahan hukum bisa diseleksi dalam bermacam bagian hukum yang meliputi, dalam bagian hukum tanah. ${ }^{10}$ Tanah adat yang awalnya secara keseluruhan diperuntukan untuk keperluan sosial, lalu beralih hanya demi mencukupi kepentingan perseorangan maupun persekutuan, maka dari itu terjadinya permasalahan adat antara masyarakat desa dengan desa. Berdasarkan hasil observasi pada kehidupan masyarakat hukum adat di Bali, di sisi lain sesungguhnya faktor yang menyebabkan kegagalan norma hukum adalah beberapa masyarakat yang sadar atau tahu akan keberlakuan norma hukum, namun tetap dilanggar, yang dalam konteks ini

8 Kaban, M. (2016). Penyelesaian Sengketa Waris Tanah Adat Pada Masyarakat Adat Karo. Mimbar Hukum, 28(3), 453-465. h., 455.

9 Sirtha, I Nyoman. (2008). Aspek Hukum Dalam Konflik Adat Bali, Denpasar : Udayana Univesity Press, h. 77.

${ }^{10}$ Wayan Surpha. (2002). Seputar Desa Pakraman Dan Adat Bali, Denpasar : PT. Offset BP, h. 31. 
adalah adanya unsur kesengajaan karena didorong oleh kepentingan pribadi, seperti halnya terkait permasalahan tanah adat yang diakui sebagai hak milik pribadi, padahal sudah diatur dalam ketentuan Pasal 9 ayat (5) Peraturan Daerah Provinsi Bali Nomor 3 Tahun 2003 mengenai Desa Pakraman, namun tetap juga tanah adat menjadi suatu hal yang selalu menjadi obyek sengketa dalam kehidupan masyarakat, seperti yang terjadi di wilayah Kabupaten Badung, yang terjadi di Desa Adat Semate, permasalahan terkait sengketa tanah yang terjadi di wilayah tersebut mengingat bahwa tanah memiliki nilai ekonomi yang sangat tinggi sehingga hal tersebut juga menjadi faktor masyarakat mengabaikan norma hukum. Hal inilah yang memicu timbulnya permasalahan hukum dalam kehidupan masyarakat.

Dengan demikian, faktor yang menyebabkan banyaknya tanah adat di Bali diakui sebagai tanah hak milik pribadi ialah karena kurangnya kesadaran hukum masyarakat hukum adat untuk mentaati norma hukum dan kurangnya dukungan masyarakat dalam pelaksanaan norma hukum tersebut, namun di sisi lain dari hasil observasi terhadap perkembangan warga hukum adat di Bali, faktor selanjutnya yanh sangat berpengaruh adalah faktor kesengajaan dalam mengabaikan norma hukum, yang dalam konteks ini beberapa masyarakat hukum adat menyadari adanya norma hukum yang mengatur tentang status kepemilikan tanah namun olehnya tetap dilanggar, hal ini dipengaruhi oleh kepentingan individu, mengingat tanah memiliki nilai ekonomi yang tinggi sehingga sebagaian masyarakat mengabaikan norma hukum yang berlaku. Inilah yang dikatakan terjadinya pergeseran nilai budaya.

\subsection{Upaya Untuk Mengurangi Tanah Adat Di Bali Menjadi Tanah Milik Pribadi}

Dalam mengkaji upaya untuk mengurangi tanah adat di Bali menjadi tanah milik pribadi, sehingga digunakan teori kepastian hukum untuk menganalisis. Kepastian merupakan suatu situasi yang pasti, ketetapan atau ketentuan. Hukum pada hakekatnya harus adil dan pasti. Pasti untuk pedoman perilaku dan adil disebabkan pedoman tingkah laku tersebut wajib menopang suatu aturan yang dipandang lazim. Hal tersebut semata-mata disebabkan mempunyai sifat yang adil serta dilakukan melalui pastu suatu norma hukum bisa melakukan kegunaannya (fungsinya). Kepastian hukun merupakan persoalan yang cuma bisa dijawab secara normative bukan dengan cara sosiolog. ${ }^{11}$

Kelsen mengemukakan bahwa hukum merupakan suatu bentuk norma. Norma merupakan suatu penjelasan yang menitikberatkan pada unsur "keharusan" atau das sollen, hingga melalui berbagai aturan mengenai apa yang wajib dilaksanakan. Berbagai macam norma merupakan suatu perilaku individu yang deliberatife serta merupakan suatu produk. Perundang-undangan yang terkandung aturan-aturan yang berkarakter umum merupakan patokan untuk seseorang untuk berperilaku dalam kehidupan bermasyarakat, baik pada kaitannya terhadap antar manusia ataupun pada kaitannya terhadap kehidupan sosial.12 Peraturan-peraturan tersebut dijadikan batasan untuk masyarakat dalam melaksanakan perbuatan kepada individu, sehingga dengan

11 Rato, Dominikus. (2010). Filsafat Hukum Mencari: Memahami dan Memahami Hukum, Yogyakarta: Laksbang Pressindo, h. 59.

12 Marzuki, Peter Mahmud. (2008). Pengantar Ilmu Hukum, Jakarta : Kencana, Jakarta, h. 158. 
adanya peraturan tersebut dan pelaksanaan dari peraturan tersebut akan menimbulkan kepastian hukum.

Secara normatif kepastian hukum ialah saat aturan hukum tersebut dibuat dan diundangkan dengan cara pasti, sebab aturan hukum mengatur dengan logis dan jelas. Jelas dalam hal logis sehingga tidak mengakibatkan kesangsian (bermacam pandangan), kemudian terang pada suatu hal dapat menjadi suatu bentuk aturan terhadap aturan lain maka dari itu tidak terbentur maupun memunculkan konflik pada suatu norma. Suatu kepastian hukum merujuk terhadap memberlakukan aturan yang tetap, terang, konsekuen dan tidak berubah yang dalam konteks ini keberlangsungannya tak bisa dihasut oleh situasi-situasi yang bersifat subyektif. Keadilan serta kepastian merupakan suatu cara yang nyata berkarakter hukum, bukan hanya semata-mata dorongan moral saja, maka dari itu suatu norma yang tak pasti serta tak mau bersifat adil bukan semata-mata norma yang tidak baik.13

Utrect berpendapat yaitu pengertian suatu kepastian hukum terdiri atas dua yakni yang utama, terdapat peraturan yang berkarakter umum menjadikan seseorang tahu tindakan apa yang dapat atau tidak dapat dilaksanakan, kemudian kedua, dapat berwujud ketentraman hukum untuk seseorang dari kekuasaann pemerintah dikarenakan oleh sebab terdapat peraturan yang berkarakter umum tersebut seseorang bisa tahu apapun yang dapat dilakukan atau diwajibkan dari Negara kepada individu. ${ }^{14}$

Pemahaman kepastian hukum tersebut bersumber dari paham yuiridis-dogmatik berdasarkan dalam kesatuan pikiran postisvistis dalam bidang hukum, yang lebih memandang hukum menjadi suatu otonom yang mandiri sebab untuk yang sejalan pemahaman ini, hukum tak lain hanya gabungan peraturan. Untuk para pengikut pemahaman tersebut, suatu aturan bertujuan tak lain disebabkan oleh hanya untuk menjamin tercapainya suatu kepastian hukum. ${ }^{15}$ Kepastian hukum ini dicapai dari aturan serta karakternya yang cuma mengerjakan sesuatu peraturan hukun yang memiliki karakter umum. Karakter umum dari peraturan-peraturan hukum menyatakan bahwa hukum tak bermaksud untuk menggapai suatu rasa adil atas kegunaan, tidak lain hanya untuk suatu kejelasan (kepastian).

Kepastian hukum adalah suatu pertanggungan tentang hukum mengandung suatu rasa adil. Aturan-turan yang mengutamakan rasa adil wajib benar-benar bermanfaat sebagai aturan yag dipatuhi. Pendapat Gustav Radbruch kepastian hukum serta keadilan adalah komponen-komponen yang terkandung di dalam suatu norma. Gustav Radbruch mengemukakan kepastian hukum serta keadilahn wajib dicermati, kepastian hukum wajib dilindungi demi ketertiban serta keamanan bangsa negara,

${ }^{13}$ Ni Ketut Ardani. (2017). Kepastian Hukum Hak Komunal Ditinjau Dari Pasal 16 Ayat (1) h Undang-Undang Nompr 5 Tahun 1960. Acta Comitas Jurnal Hukum Kenotariatan Unversitas Udayana, 1. 26-42. h. 23.

${ }^{14}$ Syahrani, Riduan. (1999). Rangkuman Intisari Ilmu Hukum, Bandung : Citra Aditya Bakti, h. 23.

${ }^{15}$ Kemalasari, A. (2013). PENYELESAIAN SENGKETA KEPEMILIKAN TANAH. Diponegoro Law Journal, 2(3), 1-11. H. 36. 
sehingga pada akhirnya aturan positif wajib selalu dipatuhi. Dari teori kepastian hukum serta nilai yang akan dijunjung yaitu suatu nilai kebahagiaan serta keadilan.

Pada pembahasan ini, terkait dengan tanah adat di Bali, berdasarkan pendapat dari M. S. Dharmayuda yang mengemukakan bahwa tanah druwe desa dan atau tanah desa di Bali atau yang dengan dengan istilah lain disebut tanah adat, dapat dikelompokan dalam artian luas dan dalam artian sempit. Tanah-tanah yang tergolong pada artian luas yaitu sebagai berikut:

1. Tanah Desa

Tanah yang dimiliki ataupun yang berada dibawah penguasaan secara langsung dari desa pakraman atau yang dikenal dengan sebutan tanah desa atau tanah druwe desa ini, antara lain dikelompokan atas:

a. Tanah Pasar adalah tanah yang dipakai sebagai pembangunan pasar.

b. Tanah Lapang adalah tanah yang dimanfaatkan untuk lapangan, yang bisa dimanfaatkan sebagai sarana olahraga maupun kegiatan-kegiatan yang lainnya.

c. Tanah Kuburan (setra) adalah tanah yang dimanfaatkan untuk penguburan (lahan kuburan).

d. Tanah Bukti adalah tanah-tanah yang berupa tanah pertanian yang dalam hal ini berupa ladang atau sawah yang pemanfaatannya diserahkan kepada tokoh-tokoh desa (pejabat desa) serta terhadap pengurus desa.

2. Tanah Laba Pura

Tanah Laba Pura adalah tanah yang mulanya dimiliki oleh desa (dikuasai secara langsung oleh desa pakraman) yang secara khusus dimanfaatkan untuk kebutuhan Pura. Tanah Laba Pura dikategorikan kedalam 2 (dua) golongan yakni :

a. Tanah yang semata-mata hanya dimanfaatkan sebagai fasilitas Pura.

b. Tanah yang dimanfaatkan sebagai anggaran pembiayaan kebutuhan Pura, yang dalam hal ini, untuk perawatan ataupun kegiatan renovasi Pura dan anggaran untuk upacara-upacara yang dilaksanakan di Pura. Seiring bergantinya waktu, saat ini tanah-tanah pelaba pura tersebut status kepemilikan tanahnya telah menjadi atas nama Pura.

3. Tanah Pekarangan Desa (PKD)

Tanah pekarangan desa adalah tanah yang secara langsung berada dalam penguasaan desa, yang diserahkan kepada anggota desa (krama desa) untuk dijadikan sebagai hunian ataupun sebagai mendirikan rumah yang lazimnya untuk ukuran luas bangunannya ada batasannya dengan bangunan lain yang sama rata ukurannnya untuk masing-masing keluarga. Oleh sebab itu, terdapat kewajiban yang mewajibkan masyarakat desa yang memanfaatkan tanah pekarangan desa (PKD) adalah kewajiban yang dikenal dengan sebutan "ayahan" yang berwujud material ataupun tenaga yang diberikan teruntuk desa pakraman.

4. Tanah Ayahan Desa (AyDs)

Tanah Ayahan Desa (AyDs) adalah tanah-tanah yang penguasaannya dilaksanakan secara langsung oleh desa pakraman, selanjutnya untuk pemanfaatannya diserahkan kepada tiap-tiap masyarakat desa yang disertai hak untuk memanfaatkan hasilnya, serta dilandasi dengan suatu kewajiban 
(keharusan) untuk kesediaan melakukan "ayahan" yang berwujud materi maupun tenaga teruntuk desa pakraman. ${ }^{16}$

Dengan adanya penggolongan tanah-tanah yang berada dibawah kekuasaan desa pada uraian sebelumnya, jika dicermati, diluar tanah-tanah pada uraian di atas, ditemui juga tanah-tanah bebas dengan kata lain tanah-tanah atas hak pribadi, yang tak terbebankan oleh ayahan yang merupakan suatu kewajiban. Tanah yang berada dibawah kekuasaan perseorangan (individu) yang tak memiliki hubungan dengan konsekuensi adat merupakan tanah milik pribadi. Dalam konteks ini tanah atas hak pribadi itu bisa diwariskan kepada siapapun dan bisa dikomersilkan tanpa perlu terdapat persetujuan oleh pihak desa pakraman. Pada kenyataannya, tanah-tanah yang bersifat bebas dengan kata lain tanah-tanah yang berada dibawah kekuasan perseorangan (individu) itu belum pernah dinyatakan dengan sebutan tanah adat.

Selain penggolongan tanah adat dalam cakupan luas serta cakupan sempit, tanah adat yang berada di Bali, saat ini sudah dilaksanakannya inventarisasi yang pada konteks ini tanah yang berlandaskan atas ukuran siapa yang mempunyai serta menguasai tanah itu, oleh karena itu bisa digolongkan antara lain :

1. Tanah desa yang seluruhnya secara turun temurun dikelola dan berada dibawah kekuasaan desa pakraman. Misalnya seperti : Tanah jalan desa Tanah telajakan setra, Tanah hutan desa, Tanah lapang atau lapangan desa Tanah pasar desa, Tanah setra, Tanah tegak pura.

2. Tanah desa yang seluruhnya secara turun temurun berada dibawah kekuasaan krama desa serta dimanfaatkan seperti tanah milik pribadi yang disebut dengan istilah "tanah gunakaya" serta melakukan suatu kewajiban kepada desa pakraman, berdasarkan tatanan hukum adat yang tertulis ataupun yang tidak tertulis di desa pakraman masing-masing. Misalnya seperti : Tanah (karang teladajan desa Tanah pekarangan desa), Tanah ambal-ambal (ambal-ambal). Dapat juga dikatakan tanah atau karang ayahan desa (AYDS).

3. Tanah desa yang pada jangka waktu terbatas yang berada dibawah kekuasaan serta dimanfaatkan oleh krama desa, dikelola mempergunakan proses bagi hasil, sesuai persetujuan serta awig-awig desa pakraman yang berkaitan. Misalnya seperti : Tanah laba banjar, Tanah laba desa, Tanah atau karang ayahan desa (AYDS).

4. Tanah desa yang saat ini telah berubah dan atau bergeser menjadi tanah milik individu (tanah gunakaya). Misalnya seperti : Tanah laba pura yang disertipikatkan atas nama pemangku pura Beberapa tanah ambalambal,Tanah teba.

5. Tanah yang dipercayai menjadi tanah milik desa sebab berada di kawasan desa pakraman tertentu, berbarengan terhadap hal tersebut ada yang mempercayai sebagai tanah puri (milik keluarga bangsawan di desa pakraman tertentu) serta dipercayai sebagai tanah pura (Pura Dang Kahyangan, Pura Sad Kahyangan Pura serta Kahyangan Jagat). Berbagai pihak mengatasnamakan sudah "mempunyai dan atau menguasai " dengan

16 Alim Prabowo. (2017). Peralihan Status Kepemilikan Tanah Warisan Menjadi Tanah Pelaba Pura Dalam Masyarakat Hukum Adat Di Bali. Acta Comitas Jurnal Magister Kenotariatan Universitas Udayana, (2), 296-304. h. 87. 
cara turun temurun atau yang dsebut dengan slogan "mula suba tami" sebagai landasan "kepunyaannya". Misalnya seperti : Tanah Pura Dang Kahyangan tertentu, Tanah Pura Sad Kahyangan, Beberapa tanah Pura Kahyangan Jagat.

6. Tanah desa yang sudah bergeser peruntukannya menjadi bangunan milik pemerintah dengan tidak berlandaskan hak yang terang (jelas). Misalnya seperti : Puskesmas, Sekolah Dasar, Kantor Desa atau Kelurahan, yang didirikan di atas tanah desa.

7. Tanah desa yang sudah bergeser peruntukannya menjadi jalan untuk desa yang dibuat dengan cara gotong-royong serta dengan diam-diam sudah beralih sebagai jalan pemerintah. Misalnya seperti : Jalan desa yang dipelihara (aspal (jalan) hotmix, disertai trotoar) serta dibenahi dengan cara secara rutin melalui dana pemerintah.

8. Tanah desa yang dimanfaatkan serta berada dalam penguasaan orang lain atau pihak lain yang tak jelas, dengan berlandaskan semangat "PMP" (pongahe mekade payu). Misalnya seperti : Telajakan pura atau Telajakan desa yang dimanfaatkan oleh Pedagang Kaki Lima (PKL), dengan tidak adanya persetujuan prajuru atau melalui memanfaatkan kelengahan pengemong pura. Pertama diawali dengan menaruh meja dagangan sederhana, dilangsungkan dengan bangunan darurat, bangunan semi tetap , serta selanjutnya menjadi bangunan tetap (permanen). ${ }^{17}$

Jika dicermati pada inventarisasi mengenai tanah desa pakraman tersebut, terlihat adanya hak milik tanah desa pakraman yang lain selain dari tanah yang berada dalam penguasaan serta pemanfaatan oleh desa pakraman (krama desa). Keadaan tersebut dapat dicermati pada tanah-tanah desa yang mulanya milik dari desa pakraman kemudian berubah menjadi milik perseorangan (individu), tanah-tanah yang diyakini kepunyaan desa pakraman misalnya yang sudah dijelaskan di atas adalah tanah yang dengan cara diam-diam telah menjadi jalan pemerintah, tanah desa yang sudah berubah peruntukannya menjadi bangunan milik pemerintah yang tidak memiliki landasan hak yang terang (jelas) serta tanah desa yang berada dalam penguasaan pihak yang tidak jelas (individu yang tidak jelas). ${ }^{18}$

Berdasarkan teori kepastian hukum tersebut, maka terkait dengan upaya untuk mengurangi tanah adat di Bali menjadi tanah milik pribadi, dapat dilakukan dengan mensertifikatkan tanah-tanah adat dengan menjadikan desa pakraman sebagai subyek hukumnya. Hal ini berdasarkan Penunjukan Desa Pakraman Di Provinsi Bali Sebagai Subyek Hukum Pemilikan Bersama (Komunal) Atas Tanah pada keputusan Menteri Agraria Dan Tata Ruang Badan Pertanahan Nasional Nomor 276/KEP-19.2/X/2017. Pada keputusan tersebut, desa pakraman telah ditunjuk menjadi subyek hukum, sehingga dalam pensertifikatan tanah desa, desa pakraman dapat dijadikan sebagai

${ }^{17}$ Windia, Wayan P. (2017). Memahami Karakteristik Tanah Desa di Bali, Paper Pada Pengantar Dalam Diskusi Terfokus (FGD) Yang Diselenggarakan Oleh Badan Pertanahan Negara (BPN) Provinsi Bali, Pada Tanggal 30 Agustus 2017, Gedung Nayaka Loka, Kebun Raya Bedugul Tabanan.

18 Soearningsih, Luh Gede, 2015, Penyelesaian Sengketa Tanah Adat Yang Dijadikan Tempat Pendidikan oleh Pemerintah Daerah (Studi kasus di Desa pakramanBale agung Tenaon, Desa Alasangker, Kecamatan Buleleng, Kabupaten Buleleng), Tesis Program Magister Kenotariatan Fakultas Hukum Universitas Udayana, Denpasar, h. 53. 
subyek hukumnya. Pensertifikatan tanah ini merupakan salah satu upaya yang memiliki tujuan, antara lain :

1. Tanah desa tetap lestari sebagai tanah desa

2. Tanah desa tidak dipindahtangankan kepada pihak lain, kecuali dengan persetujuan desa pakraman

3. Pensertifikatan tanah desa tidak menganggu hubungan antara krama desa dengan tanah desa yang telah berada dalam penguasaan serta pemanfaatan dengan cara turun temurun seakan-akan milik sendiri

4. Pensertifikatan tanaah desa juga tidak menganggu hubungan antara krama desa dan tanah desa di satu pihak, dengan tanggung jawab (swadharma) yang wajib dilaksanakan oleh krama (warga) desa yang menguasai dan mengelola tanha desa terhadap desa pakraman di pihak yang lain. Baik dalam hubungan dengan tanggung jawab terhadap parahyangan, tanggung jawab terhadap pawongan, maupun tanggung jawab terhadap palemahan desa pakraman ${ }^{19}$

Adanya kepastian hukum berdasarkan Penunjukan Desa Pakraman Di Provinsi Bali Sebagai Subyek Hukum Pemilikan Bersama (Komunal) Atas Tanah pada Keputusan Menteri Agraria Dan Tata Ruang Badan Pertanahan Nasional Nomor 276/KEP19.2/X/2017, merupakan suatu payung hukum yang dapat melindungi status tanah adat di Bali dari upaya-upaya pihak-pihak yang tidak bertanggung jawab dan menjadi salah satu alternatif dalam mencegah terjadinya konflik terkait status kepemilikan tanah adat di Bali.20

Selain upaya mensertifikatkan tanah tersebut, apabila masih terjadi konflik terkait status kepemilikan tanah adat dapat juga diselesaikan dengan pendekatan hukum adat. Koesnoe mengemukakan bahwa adapun langkah untuk menuntaskan permasalahan adat melalui pendekatan hukum adat yaitu berlandaskan atas asas rukun, patut serta laras yang dapat diuraikan antara lain :

1. Asas Rukun

Pengertian rukun dalam hukm adat, dimana rukun merupakan suatu jenis asas yang dijadikan kaidah dalam menuntaskan permasalahan adat. Asas yang isinya berkaitan erat terhadap cerminan hidup serta perilaku seseorang pada suatu kehidupan sosial terhadap sesamanya, guna mewujudkan kehidupan sosial yang sejahtera, aman serta tentram yang dalam konteks ini disebut dengan asas kerukunan. Pada kehidupan sosial dalam desa adat, krama desa harus memiliki cerminan atau pemikiran, langkah-langkah serta perilaku kearah saling menerima serta memberi, dan memaafkan suatu kesalahan yang telah diperbuat oleh sesama warga desa. Hubungan yang tentram dengan sesama dalam kehidupan desa adat harus dijunjung tinggi. Digunakannya asas rukun pada penuntasan permasalahan adat bertujuan agar memulihkan suasana kehidupan seperti suasana semula,

19 A.A.Ayu Ray Saraswati. (2015-2016). Implikasi Hukum Pembebanan Hak Tanggungan Ata Tanah Hak Pengelolaan Yang Ijin Pemanfaatan Tanahnya Oleh Gubernur, Denpasar: Acta Comitas Jurnal Hukum Kenotariatan Universitas Udayana, Volume 1 Edisi 2, Denpasar, h. 67.

${ }_{20}$ Puspadwwi, Anak Agung Ayu Intan. (2018). Penunjukan Desa Pakraman Sebagai Subyek Hak Pemiikan (Komunal) Atas Tanah Berdasarkan Keputusan Menteri Agraria Dan Tata Ruang Badan Pertanahan Nasional Nomor 276/KEP-19.2/X/2017. Acta Comitas Magister Kenotariatan Universitas Udayana, h. 43. 
kehormatannya serta status, dan tercapainya hubungan yang damai antara sesama warga desa.

2. Asas Patut

Patut merupakan makna yang merujuk terhadap akal serta serta alam kesusilaan, yang diperuntukan terhadap penilaian atas suatu peristiwa sebagai perilaku manusia ataupun situasi. Asas patut juga mencakup aspek-aspek perhitungan-perhitungan yang berdasarkan hukum bisa ditoleransi yang dalam konteks ini dapat diterima secara akal sehat. Pengetahuan tentang kepatutan lebih memfokuskan status para pihak serta perhatian dalam penciptaan kualitas supaya bisa terselamatkan nama baiknya sesudah terjadi permasalahan adat. Seseorang akan selalu menjunjung tinggi kehormatan dirinya serta berusaha karena jatuhnya suatu kehormatan akan berdampak munculnya rasa malu. Penggunanaan asas patut bertujuan supaya penuntasan permasalahan adat bisa menjaga nama baik dari masing-masing pihak, oleh karena itu tak ada yang merasa dijatuhkan atau diremehkan kehormatan serta statusnya sebagai krama desa. Untuk itu, penggunaan asas patut bisa berjalan dengan baik guna menghindari munculnya permasalahan adat. Selanjutnya, pemakaian asas patut guna memperoleh keputusan pada munculnya permasalahan adat dilaksanakan dengan mencermati kelayakan, serta memperhatikan sanksi rasional serta tuntutan susila.

3. Asas Laras

Asas laras pada hukum adat dipakai dalam menuntaskan permasalahan adat yang nyata dengan adil, maka dari itu orang-orang yang berhubungan serta warga adat merasa lega. Dengan diberlakukannya penyelesaian permasalahan adat yang mencukupi kebutuhan serta naluri hukum dan kesusilaan, sehingga warga adat berlangsung kembali sebagaimana mestinya. Pemakaian pendekatan asas keselarasan dilaksanakan dengan mencermati keadaan, tempat serta waktu (desa, kala,patra) oleh karena itu putusan terhadap permasalahan bisa diterima oleh orang-orang serta masyarakat. ${ }^{21}$

Dari uraian sebelumnya, tindakan yang bisa dilaksanakan guna mencegah tanah adat di Bali menjadi tanah milik pribadi adalah dengan mensertifikatkan tanah adat tersebut dengan menjadikan desa pakraman sebagai subyek hukumnya, mengingat Penunjukan Desa Pakraman Di Provinsi Bali Sebagai Subyek Hukum Pemilikan Bersama (Komunal) Atas Tanah berdasarkan Keputusan Menteri Agraria Dan Tata Ruang Badan Pertanahan Nasional Nomor 276/KEP-19.2/X/2017, desa pakraman telah ditunjuk menjadi subyek hukum atas tanah adat di Bali Dan untuk mengatasi apabila masih terjadi konflik terkait pengakuan tanah adat di Bali sebagai tanah milik pribadi, upaya yang dapat dilakukan adalah dengan menyelesaikan permasalahan tersebut melalui mekanisme internal desa dengan menggunakan asas patut, rukun serta laras sebagai pendekatan hukum.

\section{Kesimpulan}

Faktor yang menyebabkan banyaknya tanah adat di Bali diakui sebagai tanah hak milik pribadi ialah karena kurangnya kesadaran hukum masyarakat hukum adat

21 Amahorseya, Ronald, 2008, Penyelesaian Sengketa Tanah Hak Ulayat Di Kabupaten Nabire Provinsi Papua (Studi Kasus Sengketa Tanah Bandar Udara Nabire), Tesis Program Magister Kenotariatan Universitas Diponegoro,Semarang, H. 87. 
untuk mentaati norma hukum dan kurangnya dukungan masyarakat dalam pelaksanaan norma hukum tersebut, namun di sisi lain dari hasil observasi dalam kehidupan masyarakat hukum adat di Bali, faktor selanjutnya yang sangat berpengaruh adalah faktor kesengajaan dalam mengabaikan norma hukum, yang dalam konteks ini beberapa masyarakat hukum adat menyadari adanya norma hukum yang mengatur tentang status kepemilikan tanah namun olehnya tetap dilanggar, hal ini dipengaruhi oleh kepentingan individu, mengingat tanah memiliki nilai ekonomi yang tinggi sehingga sebagian masyarakat mengabaikan norma hukum yang berlaku. Inilah yang dikatakan terjadinya pergeseran nilai budaya.

Upaya yang dapat dilakukan untuk mengurangi tanah adat di Bali menjadi tanah milik pribadi adalah dengan mensertifikatkan tanah adat tersebut dengan menjadikan desa pakraman sebagai subyek hukumnya, mengingat tentang Penunjukan Desa Pakraman Di Provinsi Bali Sebagai Subyek Hukum Pemilikan Bersama (Komunal) Atas Tanah berdasarkan Keputusan Menteri Agraria Dan Tata Ruang Badan Pertanahan Nasional Nomor 276/KEP-19.2/X/2017, desa pakraman telah ditunjuk menjadi subyek hukum atas tanah adat di Bali dan untuk mengatasi apabila masih terjadi konflik terkait pengakuan tanah adat di Bali sebagai tanah milik pribadi, upaya yang dapat dilakukan adalah dengan menyelesaikan permasalahan tersebut melalui mekanisme internal desa dengan menggunakan asas patut, laras serta rukun sebagai pendekatan hukumnya.

Masyarakat hukum adat hendaknya mentaati dan melaksanakan peraturan-peraturan ketentuan Pasal 9 ayat (5) Peraturan Daerah Provinsi Bali Nomor 3 Tahun 2003 mengenai Desa Pakraman. Terhadap Majelis Desa Pakraman dan Lembaga Perguruan Tinggi khususnya dalam bidang Kenotariatan bahwa perlu adanya suatu penyuluhan secara menyeluruh tentang pentingnya pemahaman mengenai tanah adat (desa) terhadap warga hukum adat, supaya warga adat dapat lebih memahami serta mengerti mengenai tanah adat (desa) yang paling pokok dari aspek peruntukan serta pemanfaatannya.

\section{Daftar Pustaka / Daftar Referensi}

\section{$\underline{\text { Buku }}$}

HS, H. Salim dan Erlies Septiana Nurbani, 2013, Penerapan Teori Hukum Pada Penelitian Tesis Dan Disertasi, PT RajaGrafindo Persada, Jakarta.

Marzuki, Peter Mahmud, 2008, Pengantar Ilmu Hukum, Kencana, Jakarta.

Nasution, Bahder Johan, 2008, Metode Penelitian Ilmu Hukum, Mandar Maju, Bandung.

Rato, Dominikus, 2010, Filsafat Hukum Mencari: Memahami dan Memahami Hukum, Laksbang Pressindo, Yogyakarta.

Syahrani, Riduan, 1999, Rangkuman Intisari Ilmu Hukum, Citra Aditya Bakti, Bandung.

Surpha, Wayan, 2002, Seputar Desa Pakraman Dan Adat Bali, PT. Offset BP, Denpasar.

Sirtha, I Nyoman, 2008, Aspek Hukum Dalam Konflik Adat Bali, Udayana Univesity 
Press, Denpasar.

\section{Jurnal}

Ardani, Ni Ketut. (2017). Kepastian Hukum Hak Komunal Ditinjau Dari Pasal 16 Ayat (1) $h$ Undang-Undang Nompr 5 Tahun 1960. Acta Comitas Jurnal Hukum Kenotariatan Unversitas Udayana, 1. 26-42. H. 23. URL:

https://ojs.unud.ac.id/index.php/ActaComitas/article/view/34254/20611

Ismi , Hayatul. 2013. Pengakuan Dan Perlindungan Hukum Hak Masyarakat Adat Atas Tanah Ulayat Dalam Upaya Pembaharuan Hukum Nasional. Jurnal $\begin{array}{llllll}\text { Universitas } & \text { Riau. } & 1 & \text { (3). } & \text { https }\end{array}$ ejournal.unri.ac.id/index.php/JIH/article/download/1024/1017

Kemalasari, A. (2013). PENYELESAIAN SENGKETA KEPEMILIKAN TANAH. Diponegoro Law Journal, 2(3), 1-11. URL : https://ejournal3.undip.ac.id/index.php/dlr/article/view/4198

Kusumadara, Afifah. 2013. Perkembangan Hak Negara Atas Tanah : Hak Menguasai Atau Hak Memiliki ?. Jurnal Media Hukum. 20 (2)., 263-276. https :// http://journal.umy.ac.id/index.php/jmh/article/view/267/230

Kaban, M. (2016). Penyelesaian Sengketa Waris Tanah Adat Pada Masyarakat Adat Karo. Mimbar Hukum, 28(3), 453-465. https:/ / doi.org/10.22146/jmh.16691

Prabowo, Alim (2017). Peralihan Status Kepemilikan Tanah Warisan Menjadi Tanah Pelaba Pura Dalam Masyarakat Hukum Adat Di Bali. Acta Comitas Jurnal Magister Kenotariatan Universitas Udayana, 2, 296-304. H. 87. URL : https://ojs.unud.ac.id/index.php/ActaComitas/article/view/35026/21178

Puspadewi , Anak Agung Ayu Intan. (2018). Penunjukan Desa Pakraman Sebagai Subyek Hak Pemiikan (Komunal) Atas Tanah Berdasarkan Keputusan Menteri Agraria Dan Tata Ruang Badan Pertanahan Nasional Nomor 276/KEP-19.2/X/2017. Acta Comitas Magister Kenotariatan Universitas Udayana. URL :

https://ojs.unud.ac.id/index.php/ActaComitas/article/view/39490/23947

Saraswati , A.A.Ayu Ray. 2015-2016, Implikasi Hukum Pembebanan Hak Tanggungan Ata Tanah Hak Pengelolaan Yang Ijin Pemanfaatan Tanahnya Oleh Gubernur, Acta Comitas Jurnal Hukum Kenotariatan Universitas Udayana, Volume 1 Edisi 2, Denpasar.

Sufriadi, Yanto. 2011. Penyebab Sengketa Pengadaan Tanah Untuk Kepentingan Umum (Studi KAsus Sengketa Pengadaan Tanah Untuk Kepentingan Umum Di Bengkulu). Jurnal Hukum. 1(18). 42-62. https :// www.jurnal.uii.ac.id/index.php/IUSTUM/article/download/4003/3565

Wihardi Didik. 2010, Sistem Konversi Hak Atas Tanah Adat Kampung Naga. Jurnal Sosioteknologi Institut Teknologi Bandung. 20 (9). https:// http://journals.itb.ac.id/index.php/sostek/article/view/1051/659 


\section{$\underline{\text { Tesis }}$}

Amahorseya, Ronald, 2008, Penyelesaian Sengketa Tanah Hak Ulayat Di Kabupaten Nabire Provinsi Papua (Studi Kasus Sengketa Tanah Bandar Udara Nabire), Tesis Program Magister Kenotariatan Universitas Diponegoro,Semarang.

Soearningsih, Luh Gede, 2015, Penyelesaian Sengketa Tanah Adat Yang Dijadikan Tempat Pendidikan oleh Pemerintah Daerah (Studi kasus di Desa pakramanBale agung Tenaon, Desa Alasangker, Kecamatan Buleleng, Kabupaten Buleleng), Tesis Program Magister Kenotariatan Fakultas Hukum Universitas Udayana, Denpasar.

\section{Hasil Pertemuan Ilmiah}

Windia, Wayan P., 2017, Memahami Karakteristik Tanah Desa di Bali, Paper Pada Pengantar Dalam Diskusi Terfokus (FGD) Yang Diselenggarakan Oleh Badan Pertanahan Negara (BPN) Provinsi Bali, Pada Tanggal 30 Agustus 2017, Gedung Nayaka Loka, Kebun Raya Bedugul Tabanan.

\section{Peraturan Perundang-Undangan}

Peraturan Daerah Provinsi Bali Nomor 3 Tahun 2003 tentang Perubahan Atas Peraturan Daerah Provinsi Bali Nomor 3 Tahun 2001 Tentang Desa Pakraman (Lembaran Daerah Provinsi Bali Tahun 2003 Nomor 11, Tambahan Lembaran Daerah Propinsi Bali Nomor 3)

Keputusan Menteri Agraria Dan Tata Ruang/Kepala Badan Pertanahan Nasional Nomor 276/KEP-19.2/X/2017 Tentang Penunjukan Desa Pakraman Di Provinsi Bali Sebagai Subyek Hak Pemilikan Bersama (Komunal) Atas Tanah. 